\title{
Tip Levels and Service:
}

\section{An Update, Extension, and Reconciliation}

Restaurant managers correctly believe that good tips discourage server turnover, but managers might not know the best ways to boost tips-because improving service quality doesn't necessarily do it.

BY MICHAEL LYNN

$\Lambda$ pproximately 21 million people in the United States eat out at full-service restaurants every day. ${ }^{1}$ After completing their meals, 98 percent of these people voluntarily leave a sum of money (or tip) for the servers who waited on them. ${ }^{2}$ These tips, which amount to over $\$ 20$ billion a year, are an important source of income for the nation's two

${ }^{1}$ According to Consumer Dimensions 2001 (New York: Media Dynamics, p. 194), 10 percent of the U.S. adult population eats at "sit-down or family" restaurants on an average day. With 210 million adults in the U.S., this means that about 21 million people in the U.S. eat at such restaurants each day.

${ }^{2}$ See: Pamela Paul, "The Tricky Topic of Tipping," American Demographics, May 2001, pp. 10-11.

(C) 2003, CORNELL UNIVERSITY million waiters and waitresses. ${ }^{3}$ In fact, tips often represent 100 percent of servers' take-home pay because taxes (in the form of withholding) eat up their hourly wages. ${ }^{4}$ The income implications of tipping make it a major concern of waiters and waitresscs. For that reason (among others), tipping should also be a concern of restaurant managers.

${ }^{3}$ The estimate of gross tips is based on 15 percent of full-service restaurant sales, which are estimated to have reached $\$ 143$ billion in 2001. See: National Restaurant Association, Restaurant Industry Operations Report--2001 (Washington, D.C.: National Restaurant Association, 2002). The estimate of the number of servers is from: U.S. Department of Labor, Occupational Employment Statistics, www.bls.gov (for 2002).

${ }^{4}$ See: T.A. Mason, "Why Should You Tip?," www.tip20.com (2002). 


\section{EXHIBIT 1}

\section{Semantic-differential-scale service ratings}

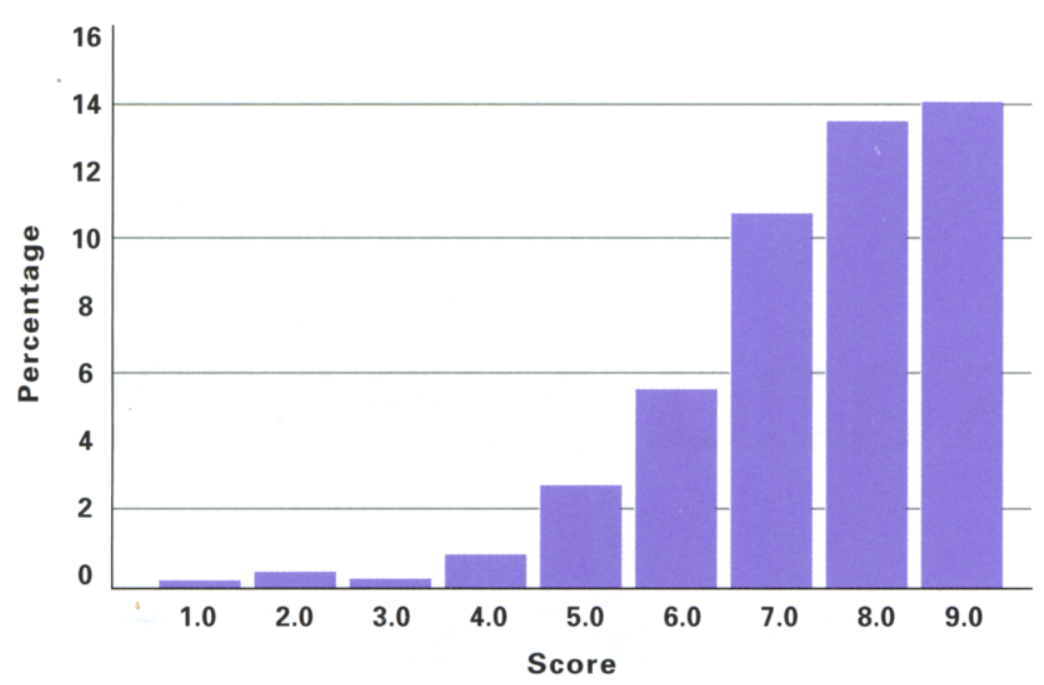

Among the questions about tipping that managers should consider are the following:

- To what extent do tips motivate good service?,

- Should tips be used to measure server performance or to identify dissatisfied guests who need placating?, and

- I low can servers' tip incomes be increased?

These managerial issues were addressed in two articles I wrote for the Cornell Hotel and Restaurant Administration Quarterly. ${ }^{5}$ However, the availability of new or previously overlooked data makes an update and extension of those articles worthwhile. Moreover, those articles contain conclusions that appear to be inconsistent with one another. In particular, one concludes that tips are only weakly related to service quality while the

\footnotetext{
5 See: Michael Lynn, "Seven Ways to Increase Servers' Tips," Cornell Hotel and Restaurant Administration Quarterly, Vol. 37, No. 3 (June 1996), pp. 24-29; and Michael Lynn, "Restaurant Tipping and Service Quality: A Tenuous Relationship," Cornell Hotel and Restaurant Administration Quarterly, Vol. 42, No. 1 (February 2001), pp. 14-20.
}

other concludes that server behavior substantially increases tips. With the apparent inconsistencies in mind, I update, extend, and reconcile those two articles here.

\section{Tips and Service Quality}

Consumcrs, cconomists, psychologists, and ctiquette experts all agree that tips are (or should be) an incentive for good service and a reward when good service actually occurs. For this reason, some restaurant managers monitor tips as a measure of server performance and customer satisfaction. Also for that reason, many restaurant managers rely on tips as the primary incentive for servers to deliver good service. Indeed, the incentive value of tips is one of the most common arguments restaurant managers raise against the adoption of automatic service charges. My 2001 Cornell Quarterly article, which examined the relationship between tipping and service, challenged these management practices. ${ }^{6}$

In a quantitative review of 14 studies involving 2,645 dining parties from 21 different restaurants, I found that the average correlation between tip percentages and service ratings was only .11. In other words, service ratings explained an average of less than 2 percent of the variation in a restaurant's tip percentages. Tips did increase with service ratings, but not by much. Moreover, those small increases were obscured by the large differences in tip percentages left by different dining parties at each level of measured service quality. This weak relationship between tipping and service quality, I argued, raises serious questions about the use of tips as a measure of server performance or customer satisfaction, as well as the use of tips as incentives to deliver good service. ${ }^{?}$

Since that time additional customer-level research on the service-tipping relationship has been published. Additionally, I have analyzed previously unpublished data on the servicetipping relationship focusing on both the servers and restaurants.

\footnotetext{
${ }^{6}$ For a fuller discussion and documentation of all the points in this paragraph, see: Lynn (2001), op. cit.

${ }^{7}$ See: Ibid.
} 


\section{New Articles}

In the two years since my 2001 Cornell Quarterly article appeared three new studies testing the service-tipping relationship have been published. These studies suggest that my conclusions about the service-tipping relationship cannot be dismissed as being the result of weak measurement and that they apply to U.S. restaurants not in my original sample as well as to restaurants outside the United States. Each of these points is discussed further below.

First, all of the studies that I reviewed used traditional rating scales where 1 represented poor service and 5 (or 10) represented excellent service. Traditional rating scales like this (known as semantic-differential scales) tend to produce ratings that are bunched at the positive end of the scale. $^{8}$ If service quality has a more normal or bell-shaped distribution, then ratings of service quality using these traditional scales will be biased and will be more weakly related to tip percentages than they should be. This possibility was tested in a study involving exit surveys of 396 dining partics at four restaurants in Ithaca, Ncw York. ${ }^{9}$ Participants were asked to rate the service using either a traditional semantic-differential scale or a new rating scale (known as the "unbounded write-in scale") that produces more normally distributed ratings. ${ }^{10}$ The distributions of service ratings produced by the two scales are presented in Exhibits 1 and 2. If the highly positive service ratings produced by the traditional scale reflect measurement bias, then the new scale should have produced a stronger correlation with

\footnotetext{
${ }^{8}$ See: R.A. Peterson and W.R. Wilson, "Measuring Customer Satisfaction: Fact and Artifact," Journal of Academy of Marketing Science, Vol. 20 (1992), pp. 61-71.

${ }^{9}$ See: Michael Lynn, "Restaurant Tips and Service Quality: A Weak Relationship or Just Weak Measurement?," International Journal of Hospitality Management, Vol. 22 (2003), pp. 321-325.

${ }^{10}$ This new scale was developed by: Eric Marder, The Laws of Choice (New York: The Free Press, 1997), pp. 150-163. This scale asks respondents to express their liking for an object by writing as many "Ls" as they feel are necessary to express how much they like it. Respondents express disliking for an object by writing as many "Ds" as they feel are necessary to express how much they dislike it. Respondents express neutral attitudes by writing an "N."
}

EXHIBIT 2

\section{Unbounded-write-in-scale service ratings}

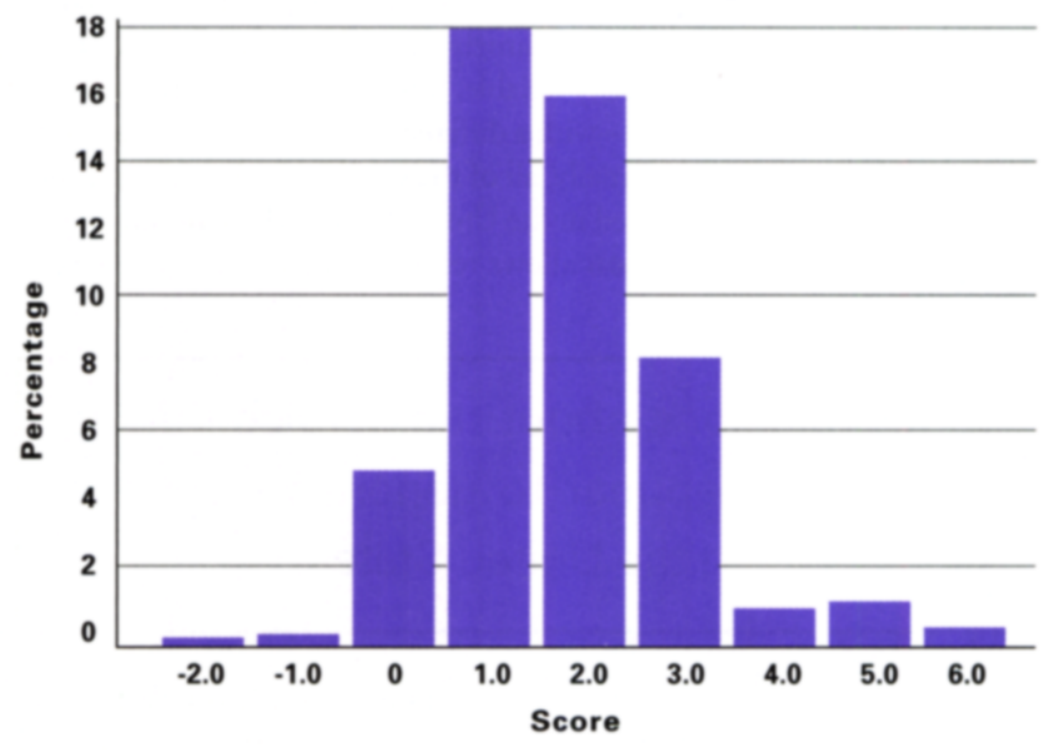

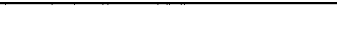

tip percentages than did the traditional scale. However, tip percentages correlated at .16 $(n=200, p<.03)$ with ratings of service quality on the unbounded scale and correlated at .19 ( $n=196, p<.01)$ with ratings of service quality on the traditional scale. These findings suggest that the skewed distributions of service quality produced by traditional rating scales are not responsible for the weak service-tipping relationship.

Second, my initial review covered studies of only 21 restaurants. Perhaps the researchers whose work I reviewed just happened to stumble across restaurants where customers do not base tips on service quality. This possibility is discounted by a study involving exit surveys with 1,393 dining parties from 39 restaurants in Houston. ${ }^{11}$ The study found that a one-point increase in service quality (as measured on a five-point scale) was associated with an increase in tips of only about

\footnotetext{
11 See: Michael Conlin, Michael Lynn, and Ted O'Donoghue, "The Norm of Restaurant Tipping," Journal of Economic Behavior and Organization, Vol. 52 (2003), pp. 297-321.
} 
1.5 percentage points. A reanalysis of the study's data produced a correlation between tip percentages and service ratings of $.07(n-1,393$, $p<.01)$. Thus, this study replicates my original finding namely, that service quality has a statistically reliable, but small effect on tip percentages-with a different sample of U.S. restaurants.

Finally, all of the studies I reviewed were conducted in the United States, where tip-credit leyislation allows restaurateurs to pay their servers

\section{My conclusions about the service-tipping relationship appear to generalize beyond the borders of the United States.}

an incentive to deliver good service. However, it does not necessarily mean that tips are weakly related to service quality if one were to look at this relationship at another level, say, by restaurant or by server. ${ }^{13}$

In that regard, it is possible that tips and service ratings are more strongly related when averaged and compared across different servers or different restaurants. If so, then tips could still be used as a measure of server or restaurant performance. At the time of my 2001 article, only two published studies provided data regarding this possibility. One study, which compared average tips and self-rated service abilities of 47 different waiters and waitresses, found a correlation of .27 between service ability and average tip after controlling for average sales and other variables. ${ }^{14}$ Another study compared managers' reports about average tips and the amount of attention their servers typically give tables in 67 different restaurants. ${ }^{15}$ Although no correlations were reported between these variables, the authors did report finding that tips were higher at restaurants where servers do extra food preparation at the table and at restaurants where servers frequently visit their tables than at restaurants where these things do not occur.

Since my 2001 Cornell Quarterly article appeared, several faculty members at the Cornell Hotel School have collected data that permit additional comparisons of tips and service across different scrvers and rcstaurants. With thcir permission, I report analyses of that unpublished data in the bullet points below.

- Alex Susskind surveyed 130 servers at eight different units in a large restaurant chain asking them to complete a measure of servers' attitude toward guests (called

All the data included in my 2001 Cornell Quarterly article were analyzed by dining party. In other words, the analyses compared tips with service ratings across different dining parties. The weak relationship between tips and service quality at this level of analysis undermines the use of tips as a measure of customer satisfaction and as

\footnotetext{
${ }^{12}$ See: Ben Dewald, "Tipping in Hong Kong Restaurants," International Journal of Hospitality Management, Vol. 22 (2003), pp. 307-319.
}

${ }^{13}$ See: Cheri Ostroff, "Comparing Correlations Based on Individual-level and Aggregated Data," Journal of Applied Psychology, Vol. 78 (1993), pp. 569-582.

${ }^{14}$ See: Michael Lynn and Tony Simons, "Predictors of Male and Female Servers' Average Tip Earnings," Journal of $A p$ plied Social Psychology, Vol. 30 (2000), pp. 241-252.

15 See: James Fitzsimmons and Gavin B. Maurer, "A Walk-through Audit to Improve Restaurant Performance," Cornell Hotel and Restaurant Administration Quarterly, Vol. 32, No. 1 (February 1991), pp. 95-99. 
guest orientation) and to indicate what tip percentages they receive on average from their customers. ${ }^{16}$ Across servers, the average tip percentage correlated at $.14(p=.11)$ with guest orientation.

- I received data on the average tip percentagc (bascd on chargccard data) and the average dining-experience ratings of mystery shoppers at 59 restaurants in the same restaurant chain mentioned above. ${ }^{17}$ The average tip percentages correlated at $-.05(p=.27)$ with the average mysteryshopper ratings.

- Bruce Tracey and Michael Tews collected data on the average charge-tip percentage, the average customer satisfaction score, and the manager's ratings of employee capabilities in 96 units of a restaurant chain different from the one above. ${ }^{18}$ For those restaurants, the average tip percentages correlated at $.14(p=.17)$ with average customer-satisfaction scores and correlated at $.16(p=.11)$ with average ratings of employees' capabilities.

\footnotetext{
${ }^{16}$ Guest orientation was measured by having respondents rate their agreement (on a 5-point scale) with the following five items: "When performing my job, the customer is most important to me"; "It is best to always ensure that our customers receive the best possible service available"; "If possible, I meet all requests made by my customers"; "As an employee responsible for providing customer service, my customers ate important to me"; and "I believe that providing timely, efficient service is a major function of my job."

${ }^{17}$ For more information about the data and restaurant chain, see: Michael Lynn, “Turnover's Relationships with Sales, lïps and Service Across Restaurants in a Chain," International Journal of Hospitality Management, Vol. 21 (2002), pp. 443-447. The correlation between average tip percentage and average mystery-shopper ratings was calculated from this study, but was not reported in the article.

${ }^{18}$ Customer-satisfaction scores were provided by an outside vendor. Employee capabilities were measured by having managers rate their agreement (on a 5-point scale) with the following five items: "Employees have the capability to respond to a wide range of customer service requests"; "Employees have the skills to meet and exceed customer expectations"; "Employees have a clear understanding of their customer-service responsibilities"; "Employees do everything in their power to meet customer needs"; and "Employees try to anticipate customer needs before requests are presented."
}

The published articles and unpublished findings presented above amplify my earlier conclusion that the relationship between service and tipping is weak. That is true when comparing across servers and restaurants just as it is when comparing across dining parties. This means that rcstaurant managers should not use their scrvers' tip averages to measure the servers' performance and that restaurant-chain executives should not use their units' average-tip percentages to measure the units' or the unit managers' performance. Mystery shoppers and customer surveys are probably better indicators of customer satisfaction than are tip averages.

\section{Increasing Servers' Tips}

As I said above, it is no revelation that tips are the major source of servers' incomes. Consequently, it seems reasonable to assume that server morale would be increased and server turnover would be reduced if servers' tip incomes were increased. In a 1996 Cornell Quarterly article, I argued that managers could reduce turnover by increasing their servers' tips. Then, I reviewed experimental evidence from the psychology literature indicating that servers earn larger tips when they take one or more of the following seven actions:

(1) introduce themselves to customers by name,

(2) squat down next to the table when interacting with customers,

(3) give customers large, open-mouthed smiles,

(4) touch customers briefly on the hand or shoulder,

(5) use tip trays embossed with credit-card insignia,

(6) write "thank you" on the backs of checks, and

(7) draw a "happy face" on the backs of checks (for waitresses, but not waiters).

Based on the evidence from the studies I reviewed, I suggested that managers train their servers to take one or more of these seven actions. Since that article, I have found evidence to support the assertion that server turnover is related to tip percentages. In addition, I have identified 


\section{Extines}

\section{Updated surmmary of experiments and quasi- experiments on restaurant tipping}

\begin{tabular}{|c|c|c|c|}
\hline \multirow[b]{2}{*}{ Tip-enhancing action } & \multicolumn{2}{|c|}{ Average Tip } & \multirow{2}{*}{$\begin{array}{l}\text { Percentage } \\
\text { increase } \\
\text { in tip }\end{array}$} \\
\hline & $\begin{array}{c}\text { Control } \\
\text { treatment }\end{array}$ & $\begin{array}{c}\text { Experimental } \\
\text { treatment }\end{array}$ & \\
\hline Introducing self by name & $15 \%$ & $23 \%$ & $53 \%$ \\
\hline $\begin{array}{l}\text { Squatting down next to table } \\
\text { Waiter } \\
\text { Waitress }\end{array}$ & $\begin{array}{l}15 \% \\
12 \%\end{array}$ & $\begin{array}{l}18 \% \\
15 \%\end{array}$ & $\begin{array}{l}20 \% \\
25 \%\end{array}$ \\
\hline Smiling & 20 cents & 48 cents & $140 \%$ \\
\hline Touching customer & $12 \%$ & $17 \%$ & $42 \%$ \\
\hline $\begin{array}{l}\text { Using tip trays with credit-card insignia } \\
\text { Restaurant } \\
\text { Cafe }\end{array}$ & $\begin{array}{l}16 \% \\
18 \% \\
\end{array}$ & $\begin{array}{l}20 \% \\
22 \%\end{array}$ & $\begin{array}{l}25 \% \\
22 \%\end{array}$ \\
\hline Writing "thank you" on check & $16 \%$ & $18 \%$ & $13 \%$ \\
\hline $\begin{array}{l}\text { Drawing a "happy face" on check } \\
\text { Waiter } \\
\text { Waitress }\end{array}$ & $\begin{array}{l}21 \% \\
28 \% \\
\end{array}$ & $\begin{array}{l}18 \% \\
33 \% \\
\end{array}$ & $\overline{18 \%}$ \\
\hline Wearing a flower in hair & \$1.50/person & $\$ 1.75 /$ person & $17 \%$ \\
\hline $\begin{array}{l}\text { Entertaining customer } \\
\text { Telling a joke } \\
\text { Giving a puzzle } \\
\end{array}$ & $\begin{array}{l}16 \% \\
19 \% \\
\end{array}$ & $\begin{array}{l}23 \% \\
22 \% \\
\end{array}$ & $\begin{array}{l}40 \% \\
18 \% \\
\end{array}$ \\
\hline Drawing a picture of sun on check & $19 \%$ & $26 \%$ & $37 \%$ \\
\hline Forecasting good weather & $19 \%$ & $22 \%$ & $18 \%$ \\
\hline Calling customer by name & $14 \%$ & $15 \%$ & $10 \%$ \\
\hline $\begin{array}{l}\text { Giving customer candy } \\
\text { Study } 1 \\
\text { Study } 2\end{array}$ & $\begin{array}{l}15 \% \\
19 \%\end{array}$ & $\begin{array}{l}18 \% \\
23 \%\end{array}$ & $\begin{array}{l}18 \% \\
21 \%\end{array}$ \\
\hline
\end{tabular}

another seven actions that servers can take to increase tips.

\section{Tips and Turnover}

In my 1996 article, I asserted (without evidence) that turnover could be reduced by increasing servers' tips. Since that timc, one recently published article and two unpublished data sets provide some support for my claim by demonstrating that restaurant-turnover rates are correlated with restaurants' tip-percentage averages and that servers' thoughts about quitting are correlated with servers' average tip percentages. These studies are briefly reviewed below.

In a recently published study, I examined the relationship between the turnover rate and the average tip percentage in 59 units of a casualdining restaurant chain. ${ }^{19}$ For all 59 restaurants and for the 30 restaurants with the highest sales volume, that relationship was weak and not statistically significant. However, in the 29 restaurants with the lowest sales volume, the average tip percentage was significantly and negatively correlated with the turnover rate $(\mathrm{r}=-.36$, onetailed $p<.03)$. This suggests that server turnover is sensitive to tip income, but that servers can acquire the tip income they need from high sales volume in addition to high tip percentages. Only when the sales volume is low are high tip percentages important in retaining waiters and waitresses.

Further supporting this conclusion are the results of another unpublished study. Bruce Tracey and Michacl Tcws's data sct, which was described previously, included a measure of turnover and a measure of the average tip percentage at 96 chain restaurants. For all 96 restaurants, turnover correlated at $-.29(p<.01)$ with average tip percentage. Moreover, this relationship was stronger among the 48 restaurants with the lowest sales volume $(r=-.36, p<.02)$ than among the 48 restaurants with the highest sales volume $(\mathrm{r}=-.23, p=.12)$.

If tip percentages affect turnover, then servers with low average tip percentages should think about quitting more than would servers who en-

\footnotetext{
${ }^{19}$ See: Lynn, 2002, op. cit.
} 
joy high average tip percentages. The unpublished data set collected by Alex Susskind provides a means of testing this expectation, because it included a measure of how often 130 servers thought about quitting as well as a measure of their average tip percentages. ${ }^{20}$

An analysis of the data indicated that servers' average tip percentages correlated at -.24 $(p<.005)$ with how of en they thought about quitting their jobs. Although not conclusive, this finding combines with those described above to support my 1996 assertion that increasing servers' tips will reduce turnover.

\section{More Ways to Increase Tips}

My 1996 article identified seven experimentally proven ways to increase servers' tips. In the paragraphs below, I identify seven more ways to increase tips. Many of these techniques have been experimentally tested (see Exhibit 3), and all of them are supported by empirical research. Although a few of the techniques may be inappropriate at some upscale restaurants, most are innocuous and can be used in restaurants of all types. Restaurant managers can increase their servers' tips by encouraging the servers to try one or more of these techniques.

Sell, sell, sell. Most restaurant customers base. their tip on a percentage of the total check (typically, 15 to 20 percent), so dollar-and-cent tip amounts should increase with check size. In fact, a recent review of research on tipping found that check size was twice a powerful as all other factors combincd in determining the sizc of tips left by different dining parties! ${ }^{21}$ This means that the best way for servers to increase their tips is to increase their sales. As explained by Sheryl Kimes in a 1999 Cornell Quarterly article, during a slow shift, sales can be increased through suggestive selling. Thus, servers should be encouraged to

\footnotetext{
${ }^{20}$ Servers rated their agreement (on a 5-point scale) with the following: "I frequently think of quitting this job at XXX."

${ }^{21}$ See: Michael Lynn and Michael McCall, "Beyond Gratitude and Gratuity: A Meta-analytic Review of the Predictors of Restaurant Tipping," unpublished manuscript at Cornell University (www.people.cornell.edu/pages/wml3/ working_papers,htm).
}

recommend appetizers, wine, expensive entrée selections, and desserts during slow shifts. However, during a busy shift, suggestive selling may be counterproductive because add-on sales may increase the customer's meal duration and slow down table turnover. Since entrées are more expensive than appetizers and desserts, servers should be encouraged to avoid suggestive selling of appetizers and desserts in favor of turning tables quickly as long as new customers are waiting to be seated. ${ }^{22}$ Increasing servers' total sales in this way directly improves the restaurant's bottom line and is the single best way to increase the servers' tip incomes. Therefore, have servers turn tables and sell more entrées when possible. When turning tables is not possible, then have servers sell more appetizers and desserts.

Personalize appearances. Wearing something unusual or distinctive is a way for servers to stand out and make customers perceive them as an individual person rather than a faceless member of the service staff. I still remember one waitress at a New York City restaurant many years ago who wore a goofy hat that no one else in the restaurant was wearing. Wearing that hat made the waitress seem more interesting and personable and increased her tip. In a related study, researchers found that waitresses increased their tips about 17 percent by wearing flowers in their hair. ${ }^{23}$ Of course, there is nothing magical about hats or flowers per se-wearing a funny necktie or some other unusual and remarkable piece of apparel should increase tips as well.

Entertain customcrs. People go to restaurants for entertainment along with their food, and they will usually reward entertaining servers with bigger tips. In one study conducted in France, waiters and waitresses at a bar gave half their customers a card with the following joke written on it:

\footnotetext{
${ }^{22}$ This insight is drawn from: Sheryl Kimes, "Implementing Restaurant Revenue Management: A Five-step Approach," Cornell Hotel and Restaurant Administration Quarterly, Vol. 40, No. 3 (June 1999), pp. 16-21.

${ }^{23}$ Jerijane Stillman and Wayne Hensley, "She Wore a Flower in Her Hair: The Effect of Ornamentation on Non-verbal Communication," Journal of Applied Communication Research, Vol. 1 (1980), pp. 31-39.
} 
An Eskimo had been waiting for his girlfriend in front of a movie theatre for a long time and it was getting colder and colder. After a while, shivering with cold and rather infuriated, he opened his coat and drew out a thermometer. He then said loudly, "If she's not here at 15, I'm leaving."

Forty-two percent of those customers getting the joke card left a tip as compared to only 25 percent of those not getting the joke card. Moreover, those who did tip left more in the joke-card condition (average tip of 23 percent) than in the no-card condition (average tip of 16 percent). ${ }^{24}$

In another study, a New Jersey waitress gave half of her customers a card with the following words: "Finished files are the result of years of scientific study combined with the experience of many years." She encouraged the customers to count the number of "fs." People often miss the fs in the word "of" because they are pronounced "v." Thus, customers were often surprised when the waitress told them the correct number of $f$ was six. They also gave her larger tips than those customers not given a card-an average tip of 22 percent, as compared to 19 percent. ${ }^{25}$ As these examples testify, servers don't have to be Robin Williams to entertain their way into a bigger tip, so let the entertainment begin!

Draw a picture on the check. Drawing cute and happy pictures on the back of checks can put customers in a good mood and may make the server seem more personable. Since people tend to be more generous when they are in a good mood and tend to be more generous to those they like, such drawings should also increase serv-

\footnotetext{
${ }^{24}$ See: Nicholas Gueguen, "The Effects of a Joke on Tipping When It Is Delivered at the Same Time as the Bill," Journal of Applied Social Psychology, Vol. 32 (2002), pp. 1955-1963.

25 See: Bruce Rind and David Strohmetz, "Effect on Restaurant Tipping of Presenting Customers with an Interesting Task and of Reciprocity," Jourrual of Applied Social Psychology, Vol. 31 (2002), pp. 1379-1384.

${ }^{26}$ See: Nicholas Gueguen and Patrick Legoherel, "Effect on Tipping of Barman Drawing a Sun on the Bottom of Customers' Checks," Psychological Reports, Vol. 87 (2000), pp. 223-226.
}

ers' tips. Consistent with this reasoning, one study conducted at a bar in France found that drawing a picture of the sun on checks increased the percentage of customers leaving a tip from 21 percent to 38 percent. ${ }^{26}$ The drawing also increased the average size of the tips that were left from 19 percent to 26 percent of the bill. Your servers need not be Picasso to draw larger tips from their customers, so cncourage them to pick up a pencil and start doodling.

Forecast good weather. Another thing that puts people in a good mood is sunny weather. Even the prospect of sunny weather elevates people's moods. This suggests that servers who live where the weather is highly variable can increase tips by telling their customers that sunny weather is on the way. 'lo test this idea, researchers had a waitress at a midscale Italian restaurant in New Jersey write a weather forecast on the backs of some of her checks but not others. The favorable weather forecast read: "The weather is supposed to be really good tomorrow. I hope you enjoy the day!" The waitress received an average tip of 22.2 percent when she forecast good weather and an average tip of 18.7 percent when she made no forecast. ${ }^{27}$ Although managers should not encourage servers to lie to customers, they may want to encourage servers to remind customers that good weather is on the way when the actual weather forecast is favorable.

Call customers by name. Calling people by their names tells them that they are considered important. Most people find such recognition flattering and enjoyable. Thus, it should not be surprising that servers get larger tips when they call their customers by name. One study documenting this effect had waiters and waitresses at several restaurants in Kansas randomly assign those customers paying by credit card to a name or a no-name condition. In the name condition, the servers noted the customers' names on their credit cards and thanked them by name (e.g., "Mr. Jones") when returning the credit cards and charge slips. In the no-name condition, servers

${ }^{27}$ See: Bruce Rind and David Strohmetz, "Effects of Beliefs About Future Weather Conditions on Tipping," Journal of Applied Social Psychology, Vol. 31 (2001), pp. 2160-2164. 
thanked the customers without mentioning their names. Customers left an average tip of 14 percent in the no-name condition and an average tip of 15.4 percent in the name condition. ${ }^{28}$ Saying two words-the customer's name-increased the servers' tips by 10 percent in this instance. This finding suggests a new answer to the old question, "What's in a name?" That answer is "bigger tips."

Give customers candy. People generally feel obligated to reciprocate when they receive gifts from others. Servers can benefit from this by giving their customers after-dinner mints or candies. Upon receiving such gifts, most customers will feel a need to reciprocate and will do so by increasing their tips. One study conducted in Ithaca, New York, found that giving customers fancy chocolates increased tips from 15 percent to 18 percent of the check. Another study conducted in New Jersey found that gifts of Hershey assorted miniature chocolates also increased tips. The highest tips were received when the server gave dining parties one piece of candy per person and then spontaneously offered them a second piece per person. In that condition, the average tip was 23 percent of the check, as compared to an average tip of 19 percent when no candy was given. ${ }^{29}$ These findings suggest that restaurant managers should consider providing after-dinner mints or other candics to be given to customers, so that their servers too can "sweeten the till."

\section{Reconciling Apparent Discrepancies}

Critical readers of my 1996 and 2001 Quarterly articles may see two apparent inconsistencies in my conclusions. First, I argue that tips are only weakly related to service quality but that they are strongly affected by server behavior. Second, I argue that differences of 2 to 3 percent of the bill

\footnotetext{
${ }^{28}$ See: Karen Rodrigue, "Tipping Tips: The Effects of Personalization on Restaurant Gratuity," master's thesis, Division of Psychology and Special Education, Emporia State University, 1999.

${ }^{29}$ Both studies are reported in: David Strohmetz, Bruce Rind, Reed Fisher and Michael Lynn, "Sweetening the Till: The Use of Candy to Increase Restaurant Tipping," Journal of Applied Social Psychology, Vol. 32 (2002), pp. 300-309.
}

are too small to be meaningful when they describe the effects on average tips of different levels of service quality, but argue that comparable differences are meaningful when they describe the effects of specific server behavior. I reconcile these issues in the paragraphs below.

Server behavior affects tips in many ways. Many people have a difficult time understanding how some server actions (such as telling customers your name, touching customers, or smil-

\section{Server behavior increases tips for many reasons-and not just because service is improved.}

ing at customers) increase tips substantially while working hard to give excellent service does not. Underlying this difficulty is the assumption that server actions can increase tips only if they improve service quality. Given that assumption, service quality should have an equally strong (if not stronger) effect on tips than does any specific server behavior. To make sense of the data on tipping, that assumption must be abandoned.

Some server actions do improve service quality. Touching customcrs, for cxamplc, has bccn shown to increase customers' ratings of service. However, server behavior increases tips for many reasons-and not just because service is improved. For example, touching customers and squatting down next to the table increase tips both because they make the server seem friendlier and because customers are loath to disappoint friendly servers. Smiling and forecasting good weather increase tips because they elevate customers' moods. Giving candy increases tips because it makes customers feel obligated to reciprocate the gift. These processes work independently of service quality and in many cases produce larger effects on tipping than does improving service.

Recognizing that many processes underlie the determination of tip levels will help managers avoid erroneous expectations about the conse- 
quences of encouraging tip-enhancing actions. At least one industry practitioner has told me that he thought an improvement in customer satisfaction is the best reason for encouraging servers to take the tip-enhancing actions that I advocate. In making that remark, this person assumed that incrcased tips indicate incrcascd customer satisfaction, but as I already said, tips are only weakly related to customer satisfaction with service. Managers should encourage tip-enhancing behavior not because it will directly improve customer satisfaction, but because it will improve server morale and reduce turnover. Happier servers may deliver better service in the long run, but the behavior that enhances servers' tips and, therefore, contributes to servers' happiness will not necessarily enhance customer satisfaction.

Weak effects are sometimes meaningful. Some of the server actions that I advocate increase tips substantially. However, others have only modest effects on tipping. For example, writing "Thank You" on the back of checks, wearing flowers in your hair, and calling customers by their names increase tips about as much as does actually improving service. Since I argue that the effect of service on tipping is too weak to be meaningful, readers are justified in asking why I consider equally weak effects involving specific server behavior to be more meaningful. The answer to that question centers on the concepts of control and certainty.

Specific actions are under servers' control more than is the guests' perception of service quality.
Performing the specific actions I've discussed is easy, and success in improving tips is certain. In contrast, improving service is difficult, and success is uncertain. Small increments in tips justify easy tasks where success is guaranteed, but not more difficult tasks where success is uncertain. Thus, weak effects on tipping are meaningful motivators of specific server behavior but not of efforts to improve service quality.

\section{Conclusion}

In two previous Cornell Quarterly articles, my reviews of research on tipping led me to several conclusions about the managerial use of tips. Since the articles appeared, researchers have collected additional data that strengthen my original arguments. Research on tipping makes it clear that:

- managers should not rely on tips to motivate good service;

- managers should not use tips to measure customer satisfaction, server performance, or restaurant performance; and

- managers should train servers to take one or more of 14 tip-enhancing actions.

These conclusions may fly in the face of restaurant managers' intuitions and of industry wisdom, but changing our perceptions of the world and our management practices is what good hospitality research and the Comell Quarterly are all about.

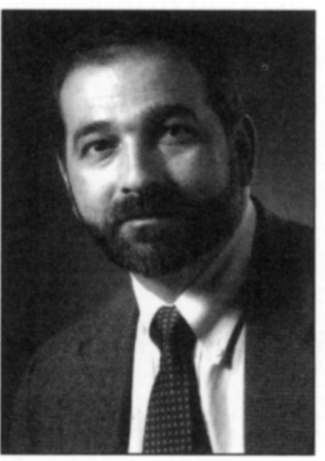

Michael Lynn, Ph.D., is an associate professor in the School of Hotel Administration at Cornell University (wml3@cornell.edu). 